\title{
Causes of Discrepancies in Value Estimates on Compensation for Oil Spill Damages in the Niger Delta
}

Michael Ayodele Olukolajo1

1 Department of Estate Management, Federal University of Technology Akure, Nigeria.

To cite this article: Olukolajo, M.A. (2019). Causes of Discrepancies in Value Estimates on Compensation for Oil Spill Damages in the Niger Delta. Journal of African Real Estate Research, 4(2), pp.42-55. DOI: 10.15641/jarer.v4i2.803.

\begin{abstract}
This study examines causes of discrepancies in valuers' opinion when determining monetary compensation payable to claimants for oil spill related damages in the Niger Delta, Nigeria. The study elicited data on factors responsible for differences in opinion of compensation values from valuers in practicing firms in Niger Delta using survey questionnaire. Eighty-three (83) Estate Surveying and Valuation (ESV) firms participated in the survey. The sample was selected from the total population of $190 \mathrm{ESV}$ firms in the region based on the evidence of their experience with oil spill compensation valuation. Weighted mean score and factor analysis were employed in the data analysis. Results indicated that the factors causing discrepancies are: weak standards/codes of practice, inadequate legal frameworks, gaps in valuers' knowledge, and professional misconduct. It was recommended that a specific code of practice for compensation for oil spill damage be developed by the Estate Surveyors and Valuers Registration Board of Nigeria (ESVARBON) in collaboration with the Nigerian Institution of Estate Surveyors and Valuers (NIESV) to guide valuers when undertaking valuation for compensation for damages arising from oil spills.
\end{abstract}

Keywords: Oil Spills; Monetary Compensation; Valuer's Opinion; Claimants; Discrepancies 


\section{Introduction}

The oil spill threat resulting from the extraction, transportation and processing of crude or refined oil requires an assessment so as to determine the compensation due to those who have suffered loss or impaired interests (Olukolajo, 2017a). Thébaud et al. (2005) noted that three categories of estimates (compensation) are usually produced in practice when determining the monetary cost of oil spills. These are estimates of damages determined by experts, claims submitted for compensation by the claimant, and ultimately, the compensation paid to the claimant. These figures often do not agree in practice. In Nigeria, many host communities to Multinational Oil Companies (MNOCs) engage in incessant conflict over the quantum of monetary compensation offered for oil spill damage (Falode, Ogedengbe \& Bickersteth, 2006; Emuedo \& Abam, 2015; Gbenemene \& Eric, 2017). In some cases, the operations of oil producing companies have been disrupted, equipment vandalized and installations destroyed, in response to dissatisfaction with degradation of the natural environment and meager compensation offered for the impaired interests (Bello \& Olukolajo, 2016a; Njoku, 2016).

Nigeria hosts the majority of MNOCs in the Niger Delta Region (NDR) and activities of oil extraction and processing began as far back as 1937. Since then, oil spills have commonly occured. Steiner (2010) reported that over the past 50 years, there have been at least 115,000 barrels of oil spillage per annum in the Niger Delta region; out of these, more than $90 \%$ have yet to be cleaned up (Okeowo, 2014). As a result, the NDR is described as the most polluted area in the world because of the menace of oil spills to fragile ecosystems (Vidal, 2010). Oluduro (2012) expressed that oil spillage in the Niger Delta has robbed people of their community development at the expense of the national development; such that their lives, traditions/culture, health, environment and way of living have been negatively impacted.

In Nigeria, Estate Surveyors and Valuers (ESVs) play a major role as professionals in determining the compensation payable to claimants. The oil companies engage valuers to determine the compensation value a claimant is entitled to for the affected interests; claimants (be it individuals, families or communities) also involve valuers to represent them and ensure that they receive adequate compensation for the impaired interests. One would expect that the valuers representing claimants and the oil companies would work hand in hand, but this is not always the case. Valuers sometimes disagree in a bid to favour their client (Odudu, 2001). The valuer representing an oil company may be conservative on the admissible claims included in the damage assessment, while the valuer representing the claimant strives to use all available means to claim substantial sums for their clients. This mostly results in two different figures emanating from the professionals, thereby complicating the compensation process. To worsen the situation, Emuedo and Abam (2015) expressed that oil companies considered oil spill situations as a condition which should rather attract sympathy for the companies and should not pay compensation to claimants. 
Where the difference in the expected compensation is much higher than the payment made to the claimants, some resort to violent conflict, threatening valuers' lives as well as disrupting the activities of oil companies. It is within this context that this study aims to identify the factors causing discrepancies in valuers' opinion on compensation payable for damages due to oil spillage in the Niger Delta, Nigeria.

\section{Literature Review}

This section reviewed some of the existing literature relevant to the subject of this study. Specifically, the first section reviewed various legislations determining the practice of oil spill damage assessment for compensation purposes, while the latter part reviewed some of the previous studies on factors causing variations in value opinion.

\subsection{Legal Provisions and Compensation Claims for Damages from Oil Spillage in Nigeria}

Valuation for the purposes of compensation is generally considered a statutory valuation, conducted under various policies, statutes and regulations that determine the basis and approach to its assessment (Kakulu et al., 2014). However, there are a number of such statutes and regulations in Nigeria that provide compensation related to the acquisition of land and landed properties, however only the Oil Pipeline Act Cap 145, LFN (1990) contains provisions that are directly related to compensation for oil spills. Others, such as Minerals Act Cap 121 of 1946, Petroleum Act No. 51 of 1969 (Now The Petroleum Act P19, LFN, 2004), Land Use Act of 1978 (now Cap L5, LFN, 2004), the Mining Act No. 24 of 1990, Oil in Navigational Water Act, Cap 337 LFN 1990 [all consolidated in the latest Laws of Federation of Nigeria (LFN, 2010)], do not directly provide for compensation for oil spill damages. On the contrary, they only refer tangentially to acquisition of land for oil and gas facilities and not primarily injurious affection (Imosemi \& Abangwu, 2013). Most of these laws prescribe adequate or fair compensation without the details of what constitute the adequacy and how to achieve it (Nuhu, 2009; Otegbulu, 2009; Kakulu \& Nuhu, 2012). It has always been a bone of contention that many claims as considered by claimants are not provided for in compensation value assessment. This often means the expected compensation is at variance with the actual payment offered to claimants.

The Oil Pipeline Act Cap 145, LFN (1990) imposed responsibility on the minister on issues related to oil fields and oil drilling; granting permission to investigate petroleum pipeline routes for transporting natural gas, mineral oil or their products for any purpose relating to the trading or operation of oil [Part II section 5(1)]. Section 6(3) allows the permit holder to enter and survey any land, but with caution to prevent unnecessary damage to the land, buildings and crop or profitable trees thereon. Section 11(5) compels the permit/license holder to compensate victims whose land is impacted or who suffers damage from oil spillage due to pipe breakage or leakage from ancillary installations. 


\subsection{Variation in Valuers' Opinion of Value}

A variation in value judgments is a measure of the difference in valuedetermining factors as expressed or interpreted by the various valuers (Boyd \& Irons, 2002). Studies have established variations in the opinion of value of valuers. Many of these studies (Baum et al., 2000; Ayedun et al,. 2012; Akinjare et al., 2013; Bello et al. 2015), however, focused on market values of real properties. Akujuru and Yalaju (2015) opined that disagreements between the valuers' opinion on value should be envisaged because the assessment combines science and art, judgment and personal perspective of the valuer. In relation to property compulsorily acquired for public interest in Finland, Hiironen et al. (2014) observed that the standard value of the market estimate offered by experienced valuers is $32 \%$ with overall change (range) of $-68 \%$ and $+113 \%$ from the median estimates. It was also found that $50 \%$ of the estimates remained within $-16 \%$ and $+33 \%$ of the median estimates. In a similar study of commercial properties in Lagos, Bello and Thomas (2015) observed a coefficient of variation in valuers' opinion of value of between $+5 \%$ and $11 \%$. Ogunba (2004) had earlier observed that the mean difference between valuation and market price in Lagos far exceeded the $+/-5 \%$ margin of error. With respect to commercial properties, Baum et al. (2000) posited that in the UK property market, an acceptable level of variation in actual value was around $+/-10 \%$ to $15 \%$.

Studies have attempted to establish the factors influencing the variation observable in valuers opinion of value. For example, experience and knowledge of valuer, characteristics of valuer and that of his firm, and valuation practices, have been found to have important implications for value variation (Babawale \& Omirin, 2012). In a study conducted on value variation in Thailand and Malaysia, Ayuthaya and Swierczek (2014) hypothesized factors that could decrease variation in valuation outcomes as: better purpose of valuation, more complete reports, better scope and assumptions, better roles of valuers, better valuer qualifications, better written confirmation, appropriate valuer conduct, better enforcement, appropriate disclosure, less conflict of interest, less client influence, and more investor confidence. Thus, the study through a regression analysis, established that the factors that were found significant to cause a decrease in variation in values are: clients' influence, incomplete reports, written confirmation, investor confidence, and the role of the valuer.

Oloyede and Durodola (2012) examined the reasons for the variance and inaccuracy in valuation in Nigeria. Factors that contribute to the variation were: a dearth of relevant market evidence/data, the use of valuation and techniques that are out-of-date, outdated valuation data, the absence of valuation controls and regulatory frameworks, a lack of valuation standards/manuals, inadequate training, failure to punish errant valuers for negligence, imperfection of the property market, the use of financial material and other forms of inducements by clients to influence the valuer, and inexperienced valuers. Among these, the lack of relevant market evidence/data, use of valuation and method techniques that are out-of-date, outdated valuation data ranked 1 st, 2 nd and 3 rd respectively. The findings in 
this research is similar to that of Effiong (2015) in which variance and accuracy in valuation between Nigeria and United Kingdom were examined. Among all the identified factors, lack of standards took 1 st place while lack of market/comparable data and lack of a regulatory framework ranked 2 nd and 3 rd respectively.

Akinjare, Iroham and Oloke (2013) categorized factors responsible for discrepancies in the value opinion of professional valuers' in Lagos, Nigeria as endogenous and exogenous factors. The former comprise adjusting values to suit recent valuations of similar properties, use of different methods of valuation, working with different parameters such as yield, and the professional experience of valuer. The latter are professional experience of valuer, clients influence on valuation, lack of adequate market information, and lack of support from other valuers conversant with the market. The prevalent margin of variance amongst valuers in the study area was attributed to the predominant use of different parameters such as yield by valuers, the use of different methods of valuation while carrying out valuation, lack of adequate market information and clients influence on valuation.

Thébaud et al. (2005) analysed several major international oil spills from tankers. These include the Amoco Cadiz accident of 16 March 1978, the Tanio oil spill at the coast of North Brittany on 7 March 1980, the Aegean Sea oil spill at the La Coruna's entrance in Spain on the 3rd of December 1992. Others are, the Braer oil spill at the South of the Shetland islands in the United Kingdom on 5 January 1993, the Sea Empress oil spill at at the entrance of the port of Milford Haven in South Wales in the United Kingdom on 15th February 1996, and the Erika accidents off the Atlantic coast of Brittany in France on the 12th December 1999. These oil spill accidents were within the International Oil Pollution Compensation Fund (IOPC Fund) in Europe. Factors found responsible for divergence in the cost estimates and compensation value included: a lack of empirical data, difficulty in determining the baseline scenario (the scenario without the occurrence of an oil spill), choice of methods of valuation, and the strategic behavior of agents involved in the compensation process.

Although studies on valuation variance with respect to compensation for compulsory land acquisition abound, there is generally a dearth of studies that have focused on compensation for oil spill damage. It is noteworthy that discrepancies in value opinions as highlighted in the above studies are diverse and are evident in both local and international valuation studies and practice; factors responsible for the discrepancies in value estimates are potential causes of inadequate compensation as reported in Bello and Olukolajo (2016b).

\section{Research Methodology and Data}

The study adopted a survey approach and data was obtained from ESV firms who are the targeted population in the NDR, Nigeria. Specifically, five out of nine states constituting the region were randomly selected. These are Ondo, Edo, Bayelsa, Rivers and Delta states. According to Eregha and Irughe, 
(2013), communities and states in the NDR have similar experiences and exhibit similar characteristics in terms of the menace of oil spills and its antecedent implication on human wellbeing as well as the natural environment. Consequently, the selected states were judged suitable to represent the region for the purpose of this study. The valuers in these ESV firms are members of the Nigerian Institution of Estate Surveyors and Valuers (NIESV); the professional association in charge of valuation in Nigeria, as well as the Estate Surveyors and Valuers Registration Board of Nigeria (ESVARBON); which regulates the practice of estate surveying and valuation in Nigeria. The ESV firms, as corporate entities, do represent oil companies, individual claimants as well as community interests depending on who engaged their services for compensation valuation. Based on the records of various branches of the NIESV in the selected states in the NDR, there are 190 registered firms to whom survey questionnaires were administered. The survey achieved a return of $123(64.74 \%)$. Out of the retrieved questionnaire, the total number of valuers who have actually been involved in oil spill damage valuations were $83,67.48 \%$ of the retrieved sample. Further analyses were based on responses obtained from this group of valuers.

Data were obtained through the use of questionnaires backed with interviews from respondents on potential factors causing differences in valuers' opinion in respect to compensation value prepared by the agent of the claimants as well as that of the oil companies. Apart from questions on personal details of the respondents and the profile of their respective firms, other questions were prepared in a 5-point Likert scale in order to enable respondents to express their opinions more explicitly. Data analysis was done descriptively using frequency tables and Weighted Mean Score (WMS). The formula for WMS is as follows:

$$
\begin{aligned}
& \qquad \operatorname{WMS}\left(\bar{x}_{W}\right)=\frac{\sum_{i=1}^{n}\left(x_{i} * w_{i}\right)}{\sum_{i=1}^{n} w_{i}} \\
& \text { Where: } \bar{x}_{W}=\text { the weighted mean variable } \\
& w_{i}=\text { the allocated weighted value } \\
& x_{i}=\text { the observed value }
\end{aligned}
$$

The study further used factor analysis combined with Principal Component Analysis (PCA). Factor analysis was used to identify, organize and minimize large elements on specific dependent variable being investigated, while PCA optimally combines variables investigated into smaller numbers.

\subsection{Suitability Test of Dataset for Factor Analysis}

The suitability of the dataset used in the Factor Analysis was performed using Bartlett's test and the Kaiser Meyer Olkin (KMO) measure of sampling adequacy measure. The two tests were conducted to determine the factorability of the matrix as a whole. The results obtained are shown in Table 1. 
Table 1: KMO and Bartlett's Test

\begin{tabular}{|c|c|c|}
\hline \multicolumn{2}{|c|}{ Kaiser-Meyer-Olkin Measure of Sampling Adequacy. } & .728 \\
\hline \multirow{3}{*}{ Bartlett's Test of Sphericity } & Approx. Chi-Square & 762.858 \\
\hline & df & 66 \\
\hline & Sig. & .000 \\
\hline
\end{tabular}

The KMO measure, as shown in Table 1 , is 0.728 , while the sphericity by means of Bartlett's test yielded a significant of $\mathrm{p}=0.000$. The result of KMO statistics ranges between 0.1 and 1 ; when it is 0 , it is unlikely that factor analysis is appropriate because the sum of partial correlations is greater than the sum of correlations, indicating diffusion in the correlations pattern. When $\mathrm{KMO}$ value is close to 1 , it denotes compactness in the pattern of correlations and factor analysis test is adjudged reliable in such instance (Hutcheson \& Sofroniou, 1999). Consequently, the KMO value in this study yielded an acceptable result (0.728), which is higher than the minimum value 0.6 commonly accepted for this type of study (Hoque \& Awang, 2016).

\section{Results and Discussion}

The results presented in this section are divided into two categories. The first describes the demographic features of respondents and their firms of practice. The second part is the empirical results of the factors responsible for differences in valuers opinion of value in compensation in the study area.

\subsection{Demographic Features of Respondents and their Firms of Practice}

This section presents the demographic characteristics of the respondents and the firms they represent and describes the demographic features of surveyed ESV firms and the surveyed respondents.

Table 2. Characteristics of the Firm/ Responding Estate Surveyors and Valuers

\begin{tabular}{|l|c|c|}
\hline Respondents' Characteristics & Frequency & Percentage \\
\hline Age of Firm & 2 & 2.41 \\
\hline Below 2 years & 6 & 7.23 \\
\hline $2-4$ years & 27 & 32.53 \\
\hline $5-6$ years & 19 & 22.89 \\
\hline $7-9$ years & 29 & 34.94 \\
\hline 10 and above & 83 & 100.00 \\
\hline Total & 9 & 10.84 \\
\hline Position of Respondent in the Firm & 28 & 33.73 \\
\hline Principal Partner & 41 & 49.40 \\
\hline Managing Partner & 5 & 6.02 \\
\hline Senior Estate Surveyor & $\mathbf{8 3}$ & $\mathbf{1 0 0 . 0 0}$ \\
\hline Staff Surveyor & \multicolumn{1}{|l|}{} \\
\hline Total & 22 & 26.51 \\
\hline Professional Status of the Respondent & 61 & 73.49 \\
\hline Fellow &
\end{tabular}




\begin{tabular}{|l|c|c|}
\hline Total & $\mathbf{8 3}$ & $\mathbf{1 0 0 . 0 0}$ \\
\hline Firm Affiliation with Local and International Professional Bodies \\
\hline NIESV & 83 & 100 \\
\hline ESVARBON & 69 & 83.13 \\
\hline FIABCI & 2 & 2.41 \\
\hline RICS & 4 & 4.82 \\
\hline
\end{tabular}

Source: Field Survey, 2015

The analysis in Table 2 indicates that the respondents' firms have been in operation for a considerable period of time. The result indicates that $90.36 \%$ of these firms have been in operation in the Niger Delta for a continuous period above five years. Results on respondents' status in their respective firms indicate that $10.84 \%$ of them were principal partners/directors of their firms; $33.73 \%$ were managing partners, while the majority of the respondents $(49.40 \%)$ were senior estate surveyors. The remaning $6.02 \%$ were staff surveyors. All sampled ESV firms are duly registered with NIESV; $26.51 \%$ of the respondents were fellows of NIESV; while $73.49 \%$ were associate members. Apart from NIESV, to which all of them belong, $83.13 \%$ have also registered with ESVARBON. In addition, some of the respondents $(2.41 \%)$ belong to the international professional body, Federation Internationale des Administrateurs de Bien-Conselis Immobiliers/ The International Real Estate Federation (FIABCI). Based on these data, it is believed that the respondents were able to provide valid responses needed in this study. Consequently, the reliability of the data obtained from them is assured.

\subsection{Factors Responsible for Differences in Valuers' Opinion of Value in Compensation Valuation}

In this section, the results of respondents' opinion on how significant they considered the identified factors responsible for discrepancies in opinion of value is presented. These factors were identified in the literature as well as interview conducted on them. Consequently, the result of this inquiry is presented in Table 3 .

\section{Table 3: Ranking of Factors Responsible for Differences in Valuers' Opinion of Value for Compensation Purpose}

\begin{tabular}{|l|c|c|c|}
\hline Causes of Differences in Valuers' Opinion of Value for Compensation Purpose & $\begin{array}{c}\text { Mean } \\
\text { Score }\end{array}$ & $\begin{array}{c}\text { Standard } \\
\text { Deviation }\end{array}$ & Rank \\
\hline Lack of or poor definition of adequate/fair compensation & 4.46 & 0.738 & 1 \\
\hline Undue influence of oil companies (polluters) & 4.34 & 0.859 & 2 \\
\hline Incomprehensiveness of heads of claims & 4.29 & 1.164 & 3 \\
\hline Lack of input from other professionals in determining value & 4.10 & 1.605 & 4 \\
\hline Inadequacy of legislation guiding compensation for oil spill damage & 4.08 & 0.940 & 5 \\
\hline Undue influence of compensation claimants & 4.01 & 1.184 & 6 \\
\hline Imposition of valuation method to be applied in assessment & 3.98 & 0.826 & 7 \\
\hline Imposition of value by the “Appropriate Officer" & 3.90 & 1.543 & 8 \\
\hline Non application of Total Economic Value concept as basis for valuation & 3.64 & 1.077 & 9 \\
\hline Differences in the valuation method applied & 3.39 & 1.584 & 10 \\
\hline Experience of the valuers & 2.88 & 1.678 & 11 \\
\hline Deliberate hiking of value to earn higher commission & 1.47 & 0.860 & 12 \\
\hline
\end{tabular}

Source: Field Survey, 2015 
From Table 3, almost all identified factors have significant influence on valuers' opinion of value. Lack of proper definition of what constitutes adequate compensation was ranked 1 st with a 4.46 mean score. Although the intent of compensation is to adequately restore the oil spill victims to the financial and economic position they were in before the spill, what is considered to be adequate is left without clear definition. Thus, valuers use their discretion based on certain assumptions to arrive at the compensation value for their clients. Undue influence of oil companies (i.e. polluters) was ranked 2 nd with a mean score of 4.34. Further information from interviews suggests that the extent to which the polluter's agent (valuer) can influence the compensation payable sometimes determine retention or renewal of contract of services with the oil company. Incomprehensiveness of heads of claims was ranked 3rd with a mean score of 4.29.

The usual OPTS (Oil Producers Trade Section) of the Lagos Chamber of Commerce and Industry; a private sector group which represents the interests of oil and gas producing companies in Nigeria, compensation schedule is used as a guiding document in damage assessment but is not all encompassing with respect to head of claims. Thus valuers differ in opinion on inclusion of certain claims in valuation reports. Lack of input from other professionals in determining value was ranked 4 th with a mean score of 4.10 . In oil spill situations, certain damages may be inflicted on land, body of waters and vegetation. Valuers require input from other expert such as soils, crop, chemical and water scientists, to determine the extent of damage and likely period of remediation/restoration in order to objectively determine the compensation value. The quality of the input is germane to the success or otherwise of the compensation exercise. Inadequacy of legislation guiding compensation for oil spill damage was ranked 5th with a mean score of 4.08. Out of the entire factors responsible for discrepancies in value, the least is hiking of compensation value by valuers in order to earn higher commission; this was ranked 12 th with a mean score of 1.47 . Although the fee charged by valuers is based on the quantum of compensation arising from a valuation assessment, the results shows that this hardly motivates valuers to influence value.

Further to the above rankings, factor analysis was conducted to classify the variables. Table 4 shows the results obtained from factor analysis and indicates that four factors were extracted. These extracted factors have their eigenvalue from 5.023 for factor one to 1.080 for factor four and all the factors accounted for $80.048 \%$ variation in the factors influencing discrepancies in valuers' opinion of value for monetary compensation for oil spill damage in NDR. 


\section{Table 4: Factors Analysis of Causes of Differences in Valuers' Opinion of Value for Oil Spill Damage Compensation}

\begin{tabular}{|c|c|c|c|c|}
\hline \multirow[t]{2}{*}{ Factors } & \multicolumn{4}{|c|}{ Component } \\
\hline & 1 & 2 & 3 & 4 \\
\hline \multicolumn{5}{|l|}{ Factor 1: Weak Standard/code of Practice } \\
\hline Lack of or poor definition of adequate/fair compensation & .758 & & & \\
\hline Incomprehensiveness of heads of claims & .932 & & & \\
\hline Undue influence of compensation claimants & .928 & & & \\
\hline Lack of input from other professionals in determining value & .935 & & & \\
\hline Variance (\%) & 41.857 & & & \\
\hline \multicolumn{5}{|l|}{ Factor 2: Inadequate Legal Framework and External Influence on Valuer } \\
\hline Imposition of method of valuation to be applied in assessment & & .733 & & \\
\hline Inadequacy of legislation guiding compensation for oil spill damage & & .669 & & \\
\hline Imposition of value by the "Appropriate Officer" & & .785 & & \\
\hline Differences in the valuation method applied & & .768 & & \\
\hline Undue influence of oil companies (polluters) & & .810 & & \\
\hline Variance (\%) & & 17.610 & & \\
\hline \multicolumn{5}{|l|}{ Factor 3: Gap in Valuers' Knowledge } \\
\hline \multicolumn{5}{|l|}{ Experience of the valuers } \\
\hline Non application of Total Economic Value concept as a basis for valuation & & & .897 & \\
\hline Variance (\%) & & & 11.579 & \\
\hline \multicolumn{5}{|l|}{ Factor 4: Professional Misconduct } \\
\hline Deliberate hiking of value to earn higher commission & & & & .931 \\
\hline Variance (\%) & & & & 9.003 \\
\hline Total Variance (\%) & & & & 80.048 \\
\hline
\end{tabular}

Source: Field Survey and Data Analysis, 2015

The first factor is named 'Weak Standard/code of Practice' and explained $41.86 \%$ of the total variance. Variables loaded under this factor are: lack of/poor definition of adequate/fair compensation; incomprehensiveness of heads of claims; undue influence of compensation claimants; and lack of input from other professionals in determining value. There is therefore the need to strengthen the standard or code of compensation valuation practice to forestall usage of different parameters for damage valuation assessment. Since impaired interests arising from oil spill damages can be enormous and diverse, valuers should, by standard or code of practice, seek input from appropriate allied professionals whose work is germane to arriving at reasonable compensation value. The launching of the 'Green Book' of ESVARBON is encouraging. However, specific code for oil spill damage valuation is necessary. Oil Spill damage compensation codes should spell the process, the bases, and appropriate method to be applied in the valuation of different heads of claims (Olukolajo, 2017b).

The second factor is tagged 'Inadequate Legal Framework and External Influence' with $17.61 \%$ of the total variance. Variables loaded under this are: imposition of method of valuation to be applied in assessment; inadequacy of legislation guiding compensation for oil spill damage; imposition of value by the appropriate officer; differences in the valuation method applied; and undue influence of oil companies. Compensation valuation in Nigeria is 
generally considered as statutory because of myriad regulations that direct its course. However, these regulations lack harmony and leave a number of issues loosely defined (Byrne \& Viitanen, 2009; Oluduro, 2012; Kakulu et al., 2014; Bodo \& Bodo, 2018).

The third factor is 'Gap in Valuers' Knowledge' with $11.58 \%$ of the total variance. Variable under this are: experience of the valuers; and non application of total economic value concept as a basis for valuation. Kayode and Ukabam (2018) highlighted the importance of valuers having appropriate technical skill, knowledge and experience as germane to successful valuation practice. A valuer who lacks all these will produce contestable values. NIESV deserves credit for the establishment of various faculties and mandating the state branches to organize Mandatory Continued Professional Development (MCPD). All these are geared towards educating their members to enhance their knowledge in professional services. However, members must continue to update their knowledge through these platforms more as attendance is voluntary.

The fourth factor is 'Professional Misconduct' having $9.00 \%$ of the total variance. The only variable under this is deliberate hiking value to earn higher commission. It is unfortunate that the drive to earn higher commission can make some valuers hike compensation claimant interest's value. ESVARBON and NIESV already have measures to deal with such unethical members. However, the measure must be strengthened and operate without fear or favour. Licenses of such a valuer may be withdrawn or have them suspended to deter potential erring members.

\section{Conclusion}

The study has identified factors causing discrepancies in valuers' opinion of compensation value for damages resulting from oil spills in the Niger Delta area of Nigeria. Through factor analysis, these factors were classified into four categories, these are: weak standards/codes of practice, inadequate legal frameworks and external influences, gaps in valuers' knowledge, and professional misconduct. A specific code of practice on oil spill damage compensation should be prepared by ESVARBON in conjunction with NIESV. The content of the code should reflect peculiarities of the claims from the Niger Delta. This will minimize the agitations in the region. Valuers must undertake training and retraining programmes as new methods and approaches are evolving towards best practices globally.

This study specifically focused on compensation for damages relating to oil pollution. Consequently, the findings herein cannot be generalised on all aspects of compensation practice. At best, the recommendation herein is specifically related to oil spill situation in the Niger Delta region of Nigeria. 


\section{References}

Akinjare, O.A., Iroham, C.O. \& Oloke, C.O. (2013). Valuation Discrepancies in the Value Opinion of Professional Valuers' in Lagos, Nigeria. International Journal of Economy, Management and Social Sciences, 2(6), pp.272-276.

Akujuru, V.A. \& Baridoma, M.B. (2007). Determinating the value of an oil/gas bearing land for compensation in a deregulated economy. Journal of Nigerian Environmental Society (JNES), 4(1), pp.100-112.

Akujuru V.A. \& Yalaju, J. (2015). The practicability of applying the total economic value to the nigerian compensation practice. (A Conceptual and Legal Analysis). The Port Harcourt Journal of Business Law, (1), pp.67-91.

Ayedun, C.A., Oloyede, S.A. \& Durodola, O.D. (2012). Empirical study of the causes of valuation variance and inaccuracy in Nigeria. International Business Research, 5(3), pp.71-80.

Ayuthaya, N.P. \& Swierczek, F.W. (2014). Factors influencing variation in value and investors' confidence. IOSR Journal of Business and Management, 16(5), pp.41-51.

Babawale, G.K. \& Omirin, M. (2012) An assessment of the relative impact of factors influencing inaccuracy in valuation. International Journal of Housing Markets and Analysis, 5(2), pp.145-160.

Babawale G.K. (2013).Emerging Issues in Compensation Valuation for Oil Spillage in the Niger Delta Area of Nigeria. Journal of Reviews on Global Economics, 2, pp.31-45

Baum, A., Crosby, N., Gallimore, P., McAllister, P. \& Gray, A. (2000). The influence of valuers and valuations on the workings of the commercial property investment market. In Royal Institution of Chatered Surveyors/Investment Property Forum, London.

Bello, M.O. \& Olukolajo, M.A. (2016a). Claimants' classification of Heads of Claims for Oil Spill Damage Assessment in Ondo State, Nigeria. In Proceedings of the Joint International Conference (JIC) on 21st Century Human Habitat: Issues, Sustainability and Development, 21 24 March 2016, Akure, Nigeria, pp.650-659

Bello M.O. \& Olukolajo M.A (2016b). Adequate Compensation as a Tool for Conflict Resolution in Oil-Polluted Wetlands of Niger Delta Region of Nigeria. Covenant University Journal of Politics \& Internationall Affairs. 4(2), pp.34-50.

Bello, V.A. \& Bello, M.O. (2009). Valuation of Properties in Close Proximity to Waste Dump Sites: The Nigeria Experience. International Journal of Strategic Property Management, 13, pp.309-317.

Bello V.A. \& Thomas O.J. (2015). Valuation Variance in the Commercial Property Market in Lagos, Nigeria. International Journal of Investment Management and Financial Innovations, 1(4), pp.105110.

Bodo T. \& Bodo C.T. (2019). The Applicability of the rule in Rylands V. Fletcher to petroleum activities in Nigeria. Asian Journal of Advanced Research and Reports, 3(1), pp.1-10. 
Boyd T. \& Irons J. (2002). Valuation Variance and Negligence: The Importance of Reasonable Care. Pacific Rim Property Research Journal. 8(2), pp.107-126.

Chua, Y P. (2009). Statistik penyelidikan lanjutan: Ujian regresi, analisis faktor dan analisis SEM. II. Buku 5. McGraw-Hill (M).

Dent, P. \& Temple, M. (1998). Economic value-a methodological dilemma. In The Cutting Edge 1998-conference proceedings.

Effiong, J.B. (2015). A comparative study of valuation variance and accuracy between Nigeria and UK. International Letters of Social and Humanistic Sciences, 57, pp.94-105.

Emuedo, C. \& Abam, M. (2015). Oil, Land Alienation and Impoverishment in the Niger Delta, Nigeria. European Journal of Research in Social Sciences. 3(2).

Eregha, P.B. \& Irughe, I.R. (2009). Oil induced environmental degradation in the Nigeria's Niger Delta: the Multiplier effects. Journal of sustainable Development in Africa, 11(4), pp.160-175.

Folade, O.A., Ogedenghe, K. \& Bickersteth, T. (2006). Managing environmental conflicts in the oil producing areas of Nigeria. Trends in Applied Sciences Research, 1, pp.259-272.

Gbenemene K. \& Eric A. (2017). Oil Compensation and Intra-Communal Conflict in the Niger Delta. Journal of Public Administration and Social Welfare Researc, 2(2), pp.48-52.

Hiironen, J., Ronen, K., Niukkanen, J.O. \& Ari Laitala, A. (2014). Margin of error'in property valuations- Is there a need for safety margins in compulsory acquisitions? In FIG Congress.

Hoque, A S.M.M. \& Awang, Z. (2016). The Exploratory Factor Analysis (EFA) of Entrepreneurial Marketing Scale- Development and Validation. In Proceeding at the Tourism Conference. 20-22 April, 2016. pp.22.

Hutcheson, G.D. \& Sofroniou, N. (1999). The multivariate social scientist: Introductory statistics using generalized linear models. London: Sage.

Imosemi A. \& Abagwu N. (2013). Compensation of Oil Spill Victims in Nigeria: The more the oil, the more the blood? Singaporean Journal of Business Economics, and Management Studies, 2(3), pp.30-43.

Kakulu I.I., Byrne P. \& Viitanen K. (2009), Phenomenological Research in Compulsory Land Acquisition and Compensation. FIG Working Week. Surveyors Key Role in Accelerated Development. Eilat, Israel, 3-8 May 2009.

Kakulu, I.I., Okorji U., Mumeya, F., Izebe S. E. \& Wokoma T.N. (2014). New compensation systems and mechanisms in the oil and gas industry in Nigeria. Researh report of National Oil Spill Detection and Response Agency (NOSDRA). DOI:10.13140/Rg.2.1.2755.4004.

Kakulu I.I. \& Nuhu M.B, (2012). A phenomenological approach to valuing Contaminated farmlands in Nigeria. The Estate Surveyor and Valuer. 37(1), pp.16-22.

Kayode, B. \& Ukabam, T. (2018). A valuation model for assessing compensation arising from oil spills in the Niger Delta Area of Nigeria. Advances in Social Sciences Research, 5(12), pp.14-29. 
Njoku, A.O. (2016). Oil pipelines vandalism and its effects on the socioeconomic development in Nigerian society. International Journal of Multidisciplinary Academic Research.4(4), pp.47-60.

Nuhu, M.B. (2009). Compulsory Purchase and Payment of Compensation in Nigeria: A Case Study of Federal Capital Territory (FCT), Abuja. Nordic Journal of Surveying and Real Estate Research, 3.

Odudu, W.O. (2001). Standard for compensation valuation and claims in both private and public sectors. In Otegbulu A.C. Conference Proceedings from Workshop on guidelines and standards for valuation, 29-30 May.

Okeowo A. (2014). Oil thieves of the Niger Delta. Available at: http://www.bloomberg.com/bw/articles/2014-02-20/nigerias-deltaoil-thievesscrape-out-a-precarious-living\#p2.

Ogunba, O. (2004). The demand for accuracy in valuations: the case of Nigeria. Globalisation and Construction, 679.

Oluduro, O. (2012). Oil exploration and ecological damage: the compensation policy in Nigeria. Canadian Journal of Development Studies/Revue canadienne d'études du développement, 33(2), pp.164179.

Olukolajo, M.A. (2017a). Monetary Compensation for Oil Spill Damage in Niger Delta Region, Nigeria: A Question of Adequacy. Electronic scientific journal "Oil and Gas Business, 5, pp.138 - 154.

Olukolajo M.A. (2017b). Assessment of compensation valuation methods for oil polluted wetlands in Niger Delta Region, Nigeria. A Ph.D Thesis submitted to Department of Estate Management, Federal University of Technology Akure, Nigeria.

Otegbulu A. (2009). Legal and economic review of natural resources compensation valuation practice in Niger delta area of Nigeria. In RICS COBRA Research Conference, University of Cape Town, 1011th September, pp.1763-1777.

Steiner, R. (2010). Double standard: Shell practices in Nigeria compared with international standards to prevent and control pipeline oil spills and the Deepwater Horizon oil spill. Milieudefensie (Friends of the Earth Netherlands), Amsterdam.

Thébaud, O., Bailly, D., Hay, J. \& Pérez, J. (2005). The cost of oil pollution at sea: an analysis of the process of damage valuation and compensation following oil spills. Economic, Social and Environmental Effects of the Prestige Oil Spill de Compostella, Santiago, pp.187-219.

Vidal, J. (2010). Nigeria's agony dwarfs the Gulf oil spill: The US and Europe Ignore It. The Guardian Newspaper. Available at: https://www.theguardian.com/world/2010/may/30/oil-spills-nigerianiger-delta-shell 